\title{
Management of hypertension: summary of NICE guidance
}

\begin{abstract}
In a rapid response to this Practice article by Taryn Krause and colleagues (BMJ 2010;343:d4891 doi:10.1136/bmj.d4891), Kate Harding and colleagues write that it "does not mention that women of child bearing potential should not be treated with either ACE inhibitors or ARBs without a detailed discussion of the teratogenic potential of these drugs, and advice to

discontinue them preferably prior to conception" (www.bmj. com/content/343/bmj.d4891.extract/reply\#bmj_el_269620). In
\end{abstract}

reply, the authors acknowledge the omission from this summary document but point out that the full NICE guidance does contain specific recommendations on the subject (www.bmj.com/ content/343/bmj.d4891.extract/reply\#bmj_el_270204).

Cite this as: BMJ 2011;343:d6255

๑ BMJ Publishing Group Ltd 2011 